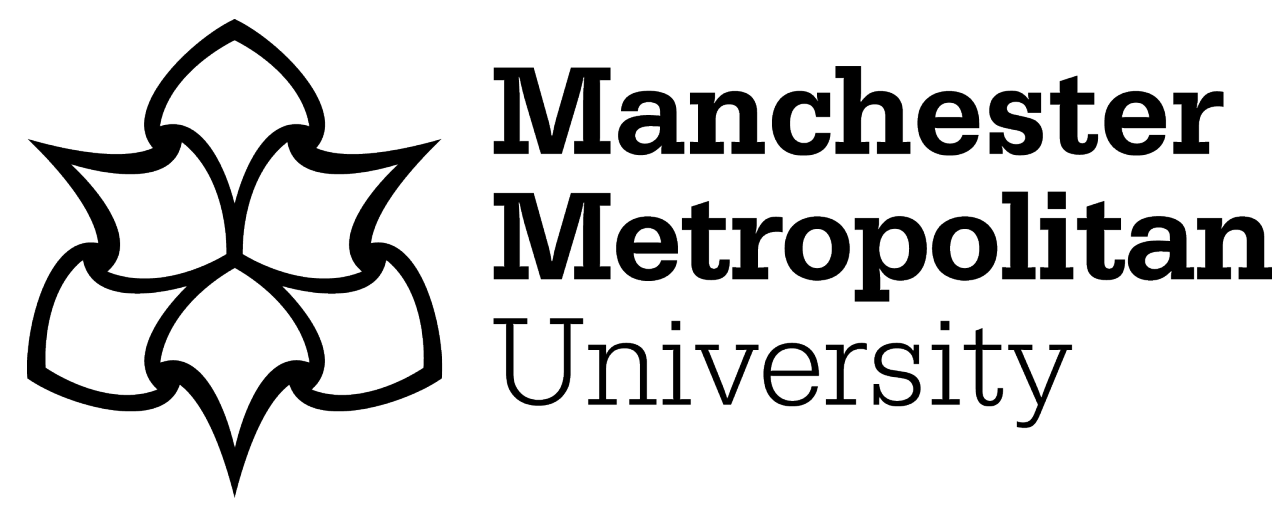

Leal Filho, W, Otoara Ha'apio, M, Lütz, JM and Li, C (2020) Climate change adaptation as a development challenge to small Island states: A case study from the Solomon Islands. Environmental Science and Policy, 107. pp. 179187. ISSN 1462-9011

Downloaded from: https://e-space.mmu.ac.uk/625652/

Version: Accepted Version

Publisher: Elsevier

DOI: https://doi.org/10.1016/j.envsci.2020.03.008

Please cite the published version 


\title{
Climate Change Adaptation as a Development Challenge to Small Island States: A Case Study from the Solomon Islands
}

\author{
Walter Leal Filho a , Michael Otoara Haapio ${ }^{b}$, Johannes M. Lütz ${ }^{c}$, Chunlan Lid*
}

Environmental Science and Policy 107:179-187 01 May 2020 DOI

https://www.sciencedirect.com/science/article/abs/pii/S1462901119304824?via\%3Dihub

(1)

11

a. Hamburg University of Applied Sciences, Germany \& School of Science and Environment, Manchester Metropolitan University, Chester Street Manchester, M1 5GD, UK w.1eal@mmu.ac.uk

b. Pacific Centre for Environment and Sustainable Development, University of the South Pacific, Suva, Fiji mhaapio@gmail.com

c. School of Social Sciences, CHC Higher Education, Carindale, QLD 4152, Australia jluetz@chc.edu.au ; University of New South Wales (UNSW), Sydney, NSW 2052, Australia j.luetz@unsw.edu.au

d. Key Laboratory of Geographic Information Science (Ministry of Education) and School of Geographical Sciences, East China Normal University, Shanghai 200241, China. E-mail: 15598022233@163.com

*Corresponding author: Chunlan Li

\begin{abstract}
Small Island Developing States (SIDS) are known to be particularly vulnerable to climate change, which poses a challenge to their economic and social development, and is a cause of hardship to their populations. This vulnerability is expressed in several ways, from exposure to sea level rises, to salt intrusion, and extensive droughts in some areas. Despite this rather negative trend, there are examples of initiatives where the vulnerability of SIDS can be reduced, and their resilience may be increased. Based on the paucity of the literature on concrete examples of successful climate change adaptation initiatives on SIDS, this paper presents an overview of pertinent challenges faced, and introduces two case studies from the Solomon Islands, which illustrate how much can be achieved by systematically pursuing adaptation strategies. The novelty of this paper resides on the fact that is one of the few pieces which have attempted to focus on successful climate change adaptation initiatives on Solomon Islands (a nation seldom represented in the literature). The paper not only presents an overview of pertinent challenges faced, but also introduces two case studies from the Solomon Islands, which illustrate how much can be achieved by systematically pursuing adaptation strategies. The lessons learned from these case studies are outlined, and some useful insights are provided, which may help SIDS to better foster the development opportunities with climate change adaptation offers to them.
\end{abstract}


39 Keywords: Climate change; Adaptation; Solomon Islands; Development; Migration 40

41 


\section{Introduction: an overview of climate change in Small Island Developing States and stressors and development barriers on the Solomon Islands}

Small Island Developing States (SIDS) are known to be vulnerable to climate change due to a combination of factors (Nurse et al 2014). Impacts of climate change to island nations are manifold and may include areas as varied as:

- Human Systems

- Island Settlements and Tourism

- Human Health

- Relocation and Migration

- Economic development

- Structure of coastal areas

(Nurse et al 2014, Leal Filho 2019)

According the 5th Assessment Report produced by the Intergovernmental Panel on Climate Change (IPCC) SIDS are prone to be affected by sea level rise (IPCC 2014). The Report "Global Warming of of $1.5^{\circ} \mathrm{C}$ " has stated that increases in temperature may exacerbate sea level rise and put island nations at a greater risk (IPCC 2018). Figure 1 presents a schematic view of how climate change influences SIDS.

\section{Figure 1- Some of the influences of climate change to SIDS}

The Pacific region offers no exception and suffers similar influences. There is also a multitude of climate change-related risks and impacts which affects the region as a whole (Leal Filho 2017) and coastal communities in particular (Leal Filho 2018), including the Solomon Islands, the country studied on this paper.

The Solomon Islands is a small island developing State (SIDS) located in the Southwest Pacific about 1,900 km northeast of Australia (Figure 2), with 996 islands stretching in a 1,450-kilometer chain southeast from Papua New Guinea (Coleman \& Kroenke 1981).

Figure 2: Pacific Island countries and Territories

The country has a population of around 537,000 inhabitants who share a total land area of approximately $27,500 \mathrm{~km}^{2}$. Its nominal GDP was estimated by the World Bank in 2017 at approximately US $\$ 1.202$ billion (Ozturk et al., 2016). The country's undeveloped mineral resources include lateritic bauxite, lead, nickel, and zinc (Asian Development Bank, 2017). Manufacturing primarily involves the processing of coconut and other vegetable oils and of cocoa on the islands. Traditional handicrafts, 
including woodwork, shell inlay, mats, baskets, and shell jewelleries, are made both for the tourist market and for export. The Solomon Islands Dollar (SBD) is the official currency, which currently is weighted SBD \$7.60 against USD\$1. Tourism has been developed but is not a major source of income (World Bank, 2010). The country's main resources, fish and timber, have been exploited excessively, which has resulted in their progressive depletion (Foster \& Laracy, 2017). Its other export products are derived from plantation crops: palm oil, copra and cacao (the source of cocoa). China and Australia are the major recipients of these exports. The chief imports are machinery, fuels, manufactured goods, and food, with Australia, Singapore, and China constituting the main suppliers. ${ }^{1}$

About 85 per cent of the population live in rural villages located within $1.5 \mathrm{~km}$ from the coastline (Gagahe, 2011) and derive their livelihoods directly from the environment. Like other Small Island Developing States (SIDS), the Solomon Islands are vulnerable to the adverse impacts of climate change (Barnett, 2011) and are heavily dependent on aid money for most development programs. This exemplifies the fact that climate change poses a barrier to their economic development and social well being. Extreme climate events like tropical cyclones and associated storm surges, changing rainfall patterns, droughts, rising sea levels, salt water inundation, heat stress and ocean acidification threaten people's livelihoods and affect all sectors of the country's economy (Lal et al., 2009). They also act as barriers to economic development. Further, sea level rise (SLR) in the Solomon Islands averages between 7-10 millimetres, three times the global average of 2.2 millimetres (Nunn 2013). Human resilience and survival in the face of climate change impacts largely depends on effective mitigation and adaptation strategies (Costello et al., 2009; IPCC, 2014). Adaptation has been practiced among communities in the Solomon Islands for decades through the implementation of numerous adaptation approaches and using various tools. Some approaches have been disjunctive and reactionary, while others have been anticipatory, integrated and holistic, building on traditional and cultural practices, including the wantok system $^{2}$ (Handmer, 2003).

The country's climate is tropical oceanic, i.e., hot and humid but relieved by cool winds and abundant, year-round rainfall. Temperatures seldom exceed $32^{\circ} \mathrm{C}$, and rainfall generally averages 120 140 inches $(3,000-3,500 \mathrm{~mm})$ year around (Ogo et al. 1987). Heavily wooded, mountainous terrain is characteristic, and, although there are extensive plains, only those on the northern side of Guadalcanal have been developed for large-scale agriculture (Foster \& Laracy, 2017).

As alluded to above, SLR constitutes one of the main risks facing people in parts of the Solomon Islands (Nunn, 2013). Resultant salt water intrusion can have numerous negative impacts on coastal communities. For example, parts of Malaita Island, including its atoll islands where people live in immediate proximity to the sea, face food security crises and have recently taken cautionary adaptive measures (Birk, 2012). Similar pressures exist on the Tulun Atoll where SLR related problems have

\footnotetext{
${ }^{1}$ OEC, Observation of Economic Completion: http://atlas.media.mit.edu/en/resources/about/ accessed 10/10/2017

${ }^{2}$ According to the Solomon Islands Historical Encyclopedia, "[t]he wantok system or wantokism is derived from the Solomons Pijin term for 'one talk', meaning from the same language, and implies giving preference to kin in the expectation of a series of reciprocal obligations being fulfilled.” (SIHE, 2013, para 1).
} 
precipitated a range of adverse impacts (Luetz \& Havea 2018). Importantly, the so-called GhybenHerzberg or freshwater lens is prone to salinity pollution by rising sea water (Figure 3), which in the context of sustained SLR constitutes a cogent vulnerability that tends to progressively render a lowlying island uninhabitable long before its ultimate submersion (Barnett \& Campbell 2010, p. 172).

117

Figure 3: Schematic representation of island subsistence (normal sea level) and progressive island submergence (rising sea level). (Illustration (C) World Vision, quoted from Luetz \& Havea 2018, p. 3; adapted from Aung et al 1998, p. 97)

The Langa Langa Lagoon people depend heavily on marine resources for their livelihoods, and resort to unsustainable and illegal methods of fishing (Ha'apio et al., 2014). There is no fertile land available for home gardening, thus leading and/or contributing to a situation which perpetuates these illegal fishing methods for livelihood support. The limited land available for their cultivation (Bennett, 1987) was already inundated by increasing salinity due to continuing SLR, coastal inundation and erosion.

Other parts of the country such as the Western and Temotu provinces have also experienced severe SLR (Albert, et al., 2016; Birk, 2012; Birk, \& Rasmussen 2014). In this context, five (5) islands within the Western province have already been submerged. The missing islands ranged in size from 1 to 5 hectares (2.5-12.4 acres) (Albert et al., 2016). The submerged islands were in a part of the country, which over the last two decades had seen annual sea levels rise by as much as $10 \mathrm{~mm}(0.4 \mathrm{in})$. Although these islands were not inhabited, people depended on their resources and have therefore since lost their sources of livelihood support. Further, researchers found that in the same province there were six (6) bigger islands that had large swaths of land washed into the sea, and on two of those, entire villages were destroyed and people forced to relocate (Albert et al, 2016).

In the literature, the benefits of early disaster preparedness planning, including anticipatory migration, are quite well established, and are also recognised by the UN in respect of proactive climate change adaptation: "[h]oping - and working — for the best while preparing for the worst, serves as a useful first principle for adaptation planning" (UNDP 2007, p. 198; cf. Luetz 2008, Blanco et al. 2009). Further, in terms of adaptation outcomes, the literature also seems to favour anticipatory and voluntary migration over ad hoc reactionary and forced migration responses (Foresight 2011; Luetz 2013, 2018). For example, UNHCR (2009) advocates that "early preparedness could also help avert a humanitarian catastrophe by promoting orderly movements of affected populations and increasing the viability of the move" (p. 3; see also Leighton 2012, pp. 703, 718). For example, research in the Maldives has found that "[w]hile natural disasters and environmental change can swiftly overwhelm communal coping capacities, triggering rapid and uncontrolled migration responses which are lacking in critical coordination, preparation and funding support, policy maker foresight and anticipatory preparedness can enable more benign migration processes.” (Luetz 2017, pp. 61-62). In marked contrast, pilot research conducted on the Tulun Atoll to the northeast of Bougainville, the largest island of the Solomon Islands 
archipelago, ${ }^{3}$ has found that early migration initiatives were persistently hampered due to local conditions that thwarted the timely implementation of anticipatory community relocation measures (Luetz \& Havea 2018).

In summary, it is the position of this paper that forward-looking migration initiatives represent a formidable opportunity for adaptation to climate change, which may be leveraged for human wellbeing. This position emerged ostensibly from the climate change related challenges discussed below (Section 2) through a process of in situ data collection (Section 3), and is further corroborated by this case study's analysis (Section 4) and summed up in its concluding synthesis (Section 5). The study limitations are discussed in Section 6.

\section{Overview: Climate change challenges in the Solomon Islands}

Similarly to what is observed in other SIDS ( Leal Filho 2018), the Solomon Islands face several climate change related challenges, which hinder the country's development prospects. But, despite their relevance, these have not yet been fully contextualised and analysed in an integrated way. This section of the paper aims to address this need by listing some of these challenges, including previous research performed on them, as well as arising solutions. Table 1 summarises the selected relevant literature.

Table 1: Climate change related challenges in the Solomon Islands

As Table 1 has shown, the Solomon Islands face a variety of challenges, but there are also some possible solutions. The next section of this paper discusses them.

\section{Data collection: Studying local realities and opportunities}

In order to provide a more concrete overview of the current reality data collection for this study was undertaken by a member of the research team while conducting research on the transformation of rural communities in 2015 and subsequently in 2017 (Ha'apio et al., 2018). The primary targets were a) community leaders, b) household heads, c) youth representatives, d) women groups and community representatives. The study as a whole and the selection of questions in particular, was targeted to gain new insights and perspectives on the development opportunities that communities have after experiencing extreme environmental and/or climate change related events. A total 119 people participated in the semi-structured interviews, which primarily sought to solicit qualitative information obtained from selected community leaders and youths. These were chosen based on two main criteria:

a) Community leaders are knowledgeable individuals and with the authority to implement actions

b) Household heads since these are the ones who usually provide answers o behalf of a household

\footnotetext{
${ }^{3}$ Although Bougainville Island is geographically the largest island forming part of the Solomon Islands archipelago, it is not politically a part of the nation of Solomon Islands but belongs to the Autonomous Region of Bougainville of Papua New Guinea, a region also referred to as Bougainville Province or the North Solomons.
} 
c) Young representatives, as individuals who will influence the future developments on the islands and will be the ones coping with the long-term impacts of climate change

d) Women groups and community representatives as persons of influence on the dynamics of the villages

Details on the methodological approaches, selection of respondentes and this study's preference for qualitative data (Silverman 2006) are further elaborated in Ha'apio et al. (2018, pp. 4-6). For the purpose of this paper, a focus was given on the insights from the community leaders, particularly in respect of solutions they perceive as important, in the following areas a) reconstruction strategies, b) fostering economic resilience, c) raising awareness of environmental concerns, d) minding the social impacts, e) considering water and sanitation issues f) fostering disaster preparedness and $\mathrm{g}$ ) integrated disaster preparedness and improved community governance. Since confidentiality was assured to individuals, the subsequent section only presents the views and perspectives of the surveyed community leaders, and have been anonymised to only refer to the communities and not to specific persons. Furthermore, for reasons of space the data presented referred to their views and perspectives, as they relate to the development prospects of their communities.

As far as the reliability of the data is concerned, it can be stated that, in line with standard approaches (e.g. Rothman, 2007) it is based on the seriousness of the sources, which have no reasons to lie, mislead or otherwise omit any details. Indeed, community leaders in the Pacific are among the most respected persons, and are local authorities in respect of traditions, values and law and order.

In terms of the validity of the responses provided, reference is made to Robson (2011). On this paper, the validity in the sense that the focus groups used as an instrument measures what it is designed to measure in the studied communities. Whereas the authors cannot be entirely sure that a similar study in another community would produce exactly the same results, it is clear that the method used may be deployed elsewhere and would very likely successfully collect the information and impressions from local community leaders.

\section{Results and Discussion: From adaptation to preparedness}

SIDS are exposed to an array of threats and natural hazards, which may also offer opportunities. According to Cuny (1994), when disasters occur, this may also provide opportunities for development. For example, Ong et al (2016) observe that recovery after disasters such as tsunamis provides opportunity to build back better for the impacted communities, and according to Luetz (2008), "the best time to 'build back better and stronger' is in the wake of a ... disaster" (p. 72). For example, this was noted after Typhoon Haiyan destroyed large parts of Tacloban City in the Philippines in November 2013 (McPherson et al., 2015). Such experiences align with the notion that bad things cause suffering and tragedy, but they can also destabilise the status quo, open space for new discussions, and provide an 
impetus to groups looking for positive changes. Further, governments and relevant authorities working within the recovery space across SIDS, and responding to climate change induced events such as cyclones and storm surges may be prompted to formulate more robust strategies in response to the risks and hazards facing affected coastal communities.

It is a fact that climate change adaptation efforts are needed on SIDS (Leal Filho 2015), especially those which may foster a country's development prospects. As far as solutions specific to the Solomon Islands are concerned, the subsequent section describes some of them, as well as some of the lessons learned, which may be implemented in some of the villages on the islands.

\subsection{A reconstruction strategy}

In the Solomon Islands, similar approaches were also taken at Keigold Village on Ranogha and Tapurai village on Simbo Islands. At Mondo Village there was a landslide after an earthquake, which destroyed almost one third of the village and claimed two lives. As a result, 80 per cent of the residents of the old community (Mondo village) decided to resettle at a new location now called Keigold Village, which is located $145 \mathrm{~m}$ above sea level (Ha'apio et al, 2017). While at Tapurai, the whole village was washed away by strong waves, killing 7 people in the process, with the houses being relocated 50 meters up a hill at the back of the same village (Lauer et al., 2013). This study focused mainly on how Mondo and Keigold communities responded to the extreme events including sea level rises, landslides, cyclones, and other disasters. Besides, there were several locations, where communities needed to relocate because of sea level rises (Albert et al, 2016; Birk, 2012; Luetz \& Havea, 2018). Such events provided the communities, stakeholders, provincial and national governments a fresh opportunity to cooperate and relocate the respective villagers from their old vulnerable locations near the coastlines, which are physically exposed to storm surges, rough seas, and salt water inundations (Birk \& Rasmussem, 2014). Following the resettlement of the two villages Keigold and Tapurai, the new destination sites are now located higher above sea level and have thus afforded the affected communities an opportunity to mainstream disaster risk reduction and climate change adaptation into their new village design.

The old village at Mondo was heavily populated (Interview, 8 August 2015). From observation, there will be no more space for the new families to build new homes, make new gardens or small holding farms. However, the resettlement site at the new Keigold village provides all these opportunities.

\subsection{Fostering economic resilience}

The flooding and soil erosion of coastal areas have forced affected communities to participate in mangrove rehabilitations, coral reef replanting and coastal area conservation (Ha'apio \& Gonzalez, 2015). This physically improves the communities' resilience to the impact of sea level rise and surging storms (Albert \& Schwarz 2013; Gillie, 1992). According to Lacambra et al. (2013), the mangroves have provided the villages natural barriers to cyclones and incoming waves. The coral reefs also act as an additional layer or barrier to increasing wave energy. These developments have offered opportunities 
for aid donors to provide financial assistance to the communities to improve their resilience. For example, the governments of US, Australia and Germany have provided between USD \$400 to USD \$500 million dollars for communities across the Coral Triangle Region (Indonesia, Papua New Guinea, Philippines, Solomon Islands and Timor-Leste) to rehabilitate their coral reefs (Thomas et al., 2017; Rosen \& Olsson, 2013). In the Solomon Islands, there were 89 locally managed marine protected areas (LMPA) established during the past 10 years. These LMPAs are now owned and operated by the village communities. Some of these LMPAs are established under the Coral Triangle Initiative (CTI) Program in the country.

The objective of these LMPAs is to replenish and revitalise the coral reefs so that the level of biodiversity at these areas can increase (White et al., 2014; Sulu et al, 2002). This will enable the increase in volumes and species of fish at the no-take zone and also have a flow-on effect into the areas allocated for fishing. The communities will increase the volume of their catches for sale to earn the needed income to support their livelihoods. This is an opportunity to increase the level of their adaptive capacity by increasing the socio-economic status in the community and enhance food security (Schwarz et al, 2011).

On the other hand, relocation of some of the villages provides new areas for the communities to expand into gardening or farming (Bennett, 1974; Cleasby et al, 2014; Lacey 2011; Keen \& McNeil, 2016). For example, villagers at the Keigold community participate in farming potatoes, yams, taro, cassava and other root crops for consumption with extra to sell at Gizo Township (Ha'apio et al., 2017). The extra money received now assists community members to pay for their children's school fees and basic necessities to support their households.

\subsection{Raising awareness of environmental concerns}

At the Keigold community, more young people are concerned about the future of their environment (Ha'apio et al., 2017). This is because the Mondo community cannot indefinitely support the growing size of their population into the future. Thus, relocation to Keigold village has eased the dependency that the Mondo Village people previously had on the surrounding environment to support the whole village population. Since more than 80 per cent of the households migrated to Keigold, the environment surrounding the old village is now in a better position to enable its biodiversity to replenish. This has also allowed the community to properly plan and strategize on how to implement its zoning strategy at its new location (Interview, 8 August 2015). At the new relocation site, the village is well-planned and villagers take more responsibility for looking after and taking care of their environment. For example, if a new household moves into the village, the appointed tribal leader will allocate the precise location where to build the house, in addition to the area allotted to cultivate or farm for the household. These processes also involve the cutting of trees for timber required for the household construction.

At the new site, most households now use solar for their main source of energy for lighting. At the old village, the majority used lanterns with kerosene, but with the introduction of iron roofing, many 
households have since moved to solar installations, hence reducing their level of greenhouse gas emissions.

\subsection{Minding the social Impacts}

Initially there was a split within the community on whether to move to the new Keigold site or remain at the old Mondo Village. This process created some degree of distrust amongst those who remained and those who chose to migrate to the new village. According to interviews conducted on site (8 August 2015), about 80 per cent of households who chose to relocate to the new site found that the migration process created an opportunity to rekindle a certain bond of unity amongst the villagers and their villager elder. The village elder had expressed that he felt it was his duty as chief to allocate the portion of his tribal land for the community to settle.

With the establishment of the new village at Keigold, New Zealand Aid has provided money to build a new primary school at the new site (School Principal, pers. comm. 2015). Having been built with permanent building materials, the new school has significantly increased the number of classrooms and teaching staff and enrolment overall. Prior to the relocation, the former school only enrolled students from grade 1 up to grade 4. Pupils in grades 5 and 6 were required to transfer to Buri Senior Primary School. Buri Primary School is located about $25 \mathrm{~km}$ away from this community. Now Keigold community can enrol pupils from grades 1 to 6 as the school now has the capacity to accommodate a significantly larger number of students.

There was also a new clinic built at the relocation site. The clinic established at the old village was unable to accommodate many patients at one time, and in several ways cannot compare with the new health centre (Keigold Registered Nurse, pers. comm. 2015). Hence the relocation has provided an opportunity for the provincial government to invest in a new clinic, which can now also service patients from the surrounding villages. A new church was also built at the new site with better facilities overall, including rest house and community playing field, all of which is critical for community establishment. All these new opportunities arose from the implementation of the relocation strategies.

\subsection{Considering water and sanitation issues}

At the new village, a water supply was constructed, which now distributes clean water to all the households in the community. By comparison, the old Mondo Village had leaking pipes and running taps at various locations in the village. Because of this condition, the supply of water throughout the village is progressively declining and it would be expensive to improve the entire water supply system in the village (Interview, 8 August 2015).

At the new Keigold Village, there was funding by donor aid partners for the construction of a new water supply (Village Chief, pers. comm. 2015). The funding covers construction of pipes from a new water source to a central location where water is stored in a tank. This allows the village to have enough 
supply of water when the pipe is damaged and necessary repair work is done. By comparison, the old village had no such water storage facility.

Further, toilet latrine systems are being built at various zones in the new community so that the people can use these toilet and sanitation systems rather than needing to resort to nearby bushes or coastal sea areas as used to be the custom at the old village (Interview, 9 August 2015). According to Radio New Zealand (5 August 2009), ${ }^{4}$ students from Australia and Papua New Guinea have helped construct latrines in a Solomon Islands village that had to be relocated following the devastating earthquake and tsunami in 2007. It was concluded that this contributed positively to the health and wellbeing of the new community (ibid). During diarrheal outbreaks, human wellbeing can be significantly diminished in the absence of proper toilet facilities, as was noted at the old village. The latrines were donated by an NGO, Emergency Architect Australia, and were installed by 15 students from the University of Queensland (Australia), and 2 students from the University of Lae (Papua New Guinea).

\subsection{Fostering disaster preparedness: Hard systems}

At the new village, most homes were constructed using sawn timber and iron roofing, resulting in stronger and higher building structures overall. This is similar to adoption of new building code to resist future extreme events (Bayliss-Smith, 1988; Yates \& Anderson-Berry 2004; Burslem et al, 2000) in other parts of the country. The inland movement (away from the coastline area) also implies that people are now located further away from any possible impact from Tsunamis. Secondly, the houses were built to withstand earthquakes, heavy rains and stronger winds. Furthermore, the preparedness of the village is reflected in the way villagers arranged and organised their new village. For example, they divided the village into three zones, the southern, central and northern zone. The southern end of the village is the main entrance to the village. It hosts the village heath centre (clinic) and maintains a radio connection to all other parts of the country. This is a strategic location since the health centre also serves villagers from the surrounding communities. Given this location at the entrance to the village makes it easy for villagers from other communities to avail themselves of medical services following accidents or sudden bouts of sickness (Interview, 8 August 2015). The primary school is located at the northern end of the village. This allows for the privacy of the children to attend primary education in a manner that is sheltered from the hustle of disturbances in the community. Further, children are safer at this location from any possible storm surge impacts that may cause flooding near the coastline, which is closer to the southern part of the village. At the central zone is the church building, rest house and proposed community hall. During disaster events such as cyclones, earthquakes and Tsunamis, every community member may access this safe place because of the central location in the community.

\footnotetext{
${ }^{4}$ http://www.radionz.co.nz/international/pacific-news/185236/relocated-village-in-solomon-islands-gets-new$\underline{\text { lactrines }}$
} 


\subsection{Integrated disaster preparedness: Improved community governance}

Finally, the new site has also seen the establishment of a new community governance structure (Interview, 8 August 2015) at Keigold. Besides chiefs and church leaders, a Village Organiser was appointed whose sole responsibility now is to ensure that programs and activities in the community are well planned and executed. Importantly, the role of the Village Organiser includes providing awareness to the village community on what to do in the event of a disaster. For example, during earthquakes the community members are instructed to run to the centre of the village to seek refuge. During cyclones, households are advised to store in place necessary items such as mats, kerosene lamps, or solar or battery-powered torch lights with batteries always fully charged. These measures are intended to ensure that during and following disaster events (and before relief supplies arrive), villagers have prearranged the necessary equipment and processes to adapt and survive in situ. A similar study also identified the evacuation centre in the capital Honiara to prepare for times of extreme events (Reuben \& Lowly 2016).

According to the Village Organiser, several workshops were also held following the move to the new site, which have seen multiple NGOs come and train the villagers on what to do, before, during and after disaster events. This momentum needs to be maintained as the villager population continues to increase. According to Singhal et al. (2016), the Department of Homeland Security/Federal Emergency Management Agency ${ }^{5}$ has defined disaster "preparedness" as "a continuous cycle of planning, organizing, training, equipping, exercising, evaluating, and taking corrective action in an effort to ensure effective coordination during incident response" (Homeland Security: Plan and Prepare for Disasters 2017, p. 2). This is consistent with the Ministry of Environment, Climate Change, Disaster Management and Meteorology (MECDM, 2016) policy to mainstream climate change risk reduction into adaptation strategies. The Village Chief who is also the Provincial Assembly Member confirmed this in an interview with the principal researcher.

Finally, Chief Herrick has been enlisted as a key player within a comprehensive plan for multihazard emergency management. Emergency planners should conduct a community hazard-vulnerability analysis to identify the types of environmental extremes (cyclones, earthquakes, storm surges, heavy rains and tsunamis). At the new village the community, with the assistance of the Chief and the Village Organiser, ensures that these are put in place.

\section{Conclusion: A short synthesis of the main lessons learned}

Climate change and rising sea levels are threatening the low-lying lands of the Solomon Islands and impair their development prospects. In the Lau Lagoon, low-lying coastal areas of Malaita, and elsewhere on atolls, the impacts of climate change on rural populations are especially conspicuous. The combination of sea level rises, and extreme events such as floods and extended periods of drought, means that the livelihoods of thousands of people in the country are under significant pressure. As this

\footnotetext{
${ }^{5}$ https://www.dhs.gov/topic/plan-and-prepare-disasters
} 
paper has shown, SIDS such as the Solomon Islands face a wide range of pressures from climate change and there is a pressing need to find reliable ways to adapt to these new challenges.

Understanding climate-human interactions in SIDS is an important step in addressing their problems (Nunn, Kumar 2018) and, inter-alia, in finding ways to foster their development opportunities. The examples presented in this paper, which are on the one hand specific to the Solomon Islands, are also exemplary of the diverse range of climate change related coastal pressures elsewhere in the world, on the other. They illustrate the need to seek a better understanding of climate change impacts on islands, and to identify suitable local solutions.

Apart from its focus on successful attempts of SIDS to cope with climate change, the novelty of the article resides on the fact that is one of the few pieces which have attempted to focus on successful climate change adaptation initiatives on Solomon Islands (a nation seldom represented in the literature) SIDS. The paper not only presents an overview of pertinent challenges faced, but also introduces two case studies from the Solomon Islands, which illustrate how much can be achieved by systematically pursuing adaptation strategies, especially in the Pacific region

The following bulleted shortlist highlights some of the key lessons learned and documented in this paper:

- Resettlement can be a (re)constructive adaptation response following rapid-onset disaster events such as landslides or cyclonic storm surges, but may similarly offer benefits in geographical areas prone to be affected by slow-onset problems such as anomalous precipitation or recurrent droughts.

- Resettlement related reconstruction can jump-start new projects (schools, clinics, sanitation works, latrines, clean water provision, etc.) while concurrently creating opportunities for multistakeholder collaboration that may bring together the diverse contributions of communities, provincial and national governments, donors, and development actors.

- The implementation of related adaptation measures may help communities to leapfrog stages of development, which may lead to some benefits, including reductions in greenhouse gas emissions. For example, at the relocation site, most households now use solar for their main source of energy for lighting, whereas previously kerosene was the default energy source used at the old village site.

- At the community level, the experience of rapid-onset disaster events may raise awareness on the benefits of mainstreaming disaster risk reduction and climate change adaptation measures into the planning and design processes of future villages.

- Integrated approaches can spawn or support improvements and collaborations in areas of environmental conservation or remediation (rehabilitation of mangroves, coral belts, etc.), sustainable farming practices, donor engagements, and enhanced provincial and national governance (as exemplified by the appointment of the Village Organiser). 
Finally, there remains a pressing need to ensure that climate change adaptation measures are 439 broadly agreed and indelibly supported and sustained by government over time, to ensure that the 440 Solomon Islands are able to further its economic and social development at the same time that the 441 country as a whole tries to adapt to a changing climate.

442

443

\section{Limitations}

444 The paper focused primarily on community leaders and did not examine in depth the opinion of the 445 other groups. While the above synthesised benefits and lessons learned were observed in the wake of 446 rapid-onset disaster events that resulted in reactionary relocation responses, albeit culminating in several 447 positive outcomes, there are suggestions in the literature that anticipatory migration planning in atoll 448 environments may offer further benefits and that policy maker foresight and anticipatory preparedness 449 can enable more benign migration processes." (Luetz 2017). This paper did not put an emphasis on 450 migration. Instead, it focused on other possible solutions, based on local and indigenous knowledge and 451 wisdom.

452

453 Conflict of Interest Statement

454 We declare that we have no financial and personal relationships with other people or 455 organizations. 


\section{References}

Adams, C. (2016). Community Participation and NGO Responses to the April 2014 Floods in Solomon Islands (Doctoral dissertation, ResearchSpace@Auckland).

Albert, S., Leon, J. X., Grinham, A. R., Church, J. A., Gibbes, B. R., \& Woodroffe, C. D. (2016). Interactions between sea-level rise and wave exposure on reef island dynamics in the Solomon Islands. Environmental Research Letters, 11(5), 054011.

Ancione, G., Salzano, E., Maschio, G., \& Milazzo, M. F. (2016). A GIS-based tool for the management of industrial accidents triggered by volcanic ash fallouts. Journal of Risk Research, 19(2), 212232 .

Asian Development Bank, 2015, Solomon Islands and ADB: Metro Manila, Philippines, Asian Development Bank Web site. (Accessed 03, October 2017, at http://www.adb.org/countries/solomon-islands/main .

Aung, T. H., Kaluwin, C. \& Lennon, G. W. (1998) Climate Change and Sea Level: Curriculum Modules for the Pacific Schools. Part One: Physical Science, National Tidal Facility, Flinders University of South Australia, Bedford Park, Australia.

Barnett, J. (2011). Dangerous climate change in the Pacific Islands: food production and food security. Regional Environmental Change, 11(1), 229-237.

Barnett, J. \& Campbell, J. (2010) Climate Change and Small Island States: Power, Knowledge and the South Pacific, Earthscan, London, UK.

Bennett, J. A. (1987). Wealth of the Solomons: A history of a Pacific archipelago, 1800-1978 (Vol. 3). University of Hawaii Press.

Bennett, J (1974). Cross-cultural influences on village relocation on the Weather Coast of Guadalcanal, Solomon Islands, c. 1870-1953 (Doctoral dissertation, [Honolulu]).

Birk, T. (2012). Relocation of reef and atoll island communities as an adaptation to climate change? Learning from experience in Solomon Islands. Climate Change and Human Mobility: Global Challenges to the Social Sciences. Cambridge University Press, Cambridge, 81-109.

Birk, T., \& Rasmussen, K. (2014, February). Migration from atolls as climate change adaptation: Current practices, barriers and options in Solomon Islands. In Natural Resources Forum (Vol. 38, No. 1, pp. 1-13).

Blaikie, P., Cannon, T., Davis, I., \& Wisner, B. (2014). At risk: natural hazards, people's vulnerability and disasters. Routledge.

Blanco, H., Alberti, M., Olshansky, R., Chang, S., Wheeler, S. M., Randolph, J., et al. (2009). Shaken, shrinking, hot, impoverished and informal: Emerging research agendas in planning. Progress in Planning, 72, 195-250.

Coleman, P. J., \& Kroenke, L. W. (1981). Subduction without volcanism in the Solomon Islands arc. Geo-Marine Letters, 1(2), 129-134.

Costello, A., Abbas, M., Allen, A., Ball, S., Bell, S., Bellamy, R., \& Lee, M. (2009). Managing the health effects of climate change. The Lancet, 373(9676), 1693-1733. 
Cuny, F. C. (1994). Disasters and Development. Intertect Press.

Fritz, H. M., Papantoniou, A., Biukoto, L., Albert, G., \& Wei, Y. (2014). The Solomon Islands tsunami of 6 February 2013 in the Santa Cruz Islands: field survey and modeling. In EGU General Assembly Conference Abstracts(Vol. 16).

Foresight. (2011). Migration and global environmental change: Final project report. London, UK: The Government Office for Science. Retrieved October 21, 2011, from http://www.bis.gov.uk/assets/foresight/docs/migration/11-1116-migration-and-globalenvironmental-change.pdf

Foster, S., \& Laracy, M.H. (2017). Solomon Islands, Islands and Nations, Pacific Ocean, Encyclopedia Britannica. https://www.britannica.com/place/Solomon-Islands Accessed: 10/10/2017

Gagahe N. (2011). Report on 2009 population and housing census. Solomon Islands population and housing census. National Statistic Office, Honiara, Solomon Islands Pages 1-8.

Ha'apio, M. O., \& Gonzalez, R. (2015). Building resilience to climate change impacts and socioeconomic attributes of rural households in Solomon Islands. In Climate Change in the Asia-Pacific Region (pp. 281-300). Springer International Publishing.

Ha'apio, M., Filho, W. L., Gonzalez, R., Holland, E., \& Wairiu, M. (2014). Mapping the economic costs and benefits of Coral Triangle Initiative (CTI) and Mangrove Rehabilitation Projects (MRP) in Solomon Islands: a study of two MPAs and one MRP. International Journal of Sustainable Development \& World Ecology, 21(5), 414-421.

Ha'apio, M. O, Gonzalez, R. Wairiu M., Morrison. K., \& Holland, E. (2017). Limits and Barriers to transformation: A case study of April Ridge Relocation initiative, East Honiara, Solomon Islands. In Climate change Management series. Springer International Publishing.

Ha'apio, M. O, Wairiu, M., Gonzalez, R. \& Morrison, K. (2018). Transformation of rural communities: lessons from a local self-initiative for building resilience in the Solomon Islands, Local Environment, 23:3, 352-365, DOI: 10.1080/13549839.2017.1420640

Handmer, J. (2003). 4. Adaptive Capacity: What Does It Mean. Climate change, adaptive capacity and development, 51 .

Heidarzadeh, M., Harada, T., Satake, K., Ishibe, T., \& Gusman, A. R. (2016). Comparative study of two tsunamigenic earthquakes in the Solomon Islands: $2015 \mathrm{Mw} 7.0$ normal - fault and 2013 Santa Cruz Mw 8.0 megathrust earthquakes. Geophysical Research Letters, 43(9), 4340-4349.

Homeland Security. Plan and Prepare for Disasters. Available at: http://www.dhs.gov/topic/plan-andprepare-disasters (last accessed on December 12, 2017).

IPCC. Climate change (2014). Climate Change 2014-Impacts, Adaptation and Vulnerability: Regional Aspects. Cambridge University Press.

IPCC (2018). Global Warming of $1.5^{\circ} \mathrm{C}$. IPCC, Geneva.

Kingston, J. (2016). Devastating Consequences, Flawed Responses: Assessing Japan's 3.11 Earthquake, Tsunami, and Nuclear Tragedies. Rebuilding Asia Following Natural Disasters: Approaches to Reconstruction in the Asia-Pacific Region, 367. 
Lacambra, C., Friess, D., Spencer, T., \& Moller, I. (2013). resilient natural coastal defences. The Role of Ecosystems in Disaster Risk Reduction, 82.

Lal, P. N., Kinch, J., \& Wickham, F. (2009). Review of economic and livelihood impact assessments of, and adaptation to, climate change in Melanesia.

Lauer, M., Albert, S., Aswani, S., Halpern, B. S., Campanella, L., \& La Rose, D. (2013). Globalization, Pacific Islands, and the paradox of resilience. Global Environmental Change, 23(1), 40-50.

Leal Filho, W. (Ed) (2015) Handbook of Climate Change Adaptation. Springer, Berlin.

Leal Filho, W. (Ed) (2017). Climate Change Adaptation in Pacific Countries. Fostering Resilience and Improving the Quality of Life. Springer, Cham.

Leal Filho, W. (Ed) (2018) (Ed) Climate Change Impacts and Adaptation Strategies for Coastal Communities. Springer, Berlin.

Leighton, M. (2012). Population displacement, relocation, and migration. In M. B. Gerrard \& K. Fischer Kuh (Eds.), The law of adaptation to climate change: United States and International Aspects. Chicago, USA: American Bar Association.

Leon, J. X., Hardcastle, J., James, R., Albert, S., Kereseka, J., \& Woodroffe, C. D. (2015). Supporting local and traditional knowledge with science for adaptation to climate change: lessons learned from participatory three-dimensional modeling in BoeBoe, Solomon Islands. Coastal Management, 43(4), 424-438.

Logan, J. M., Spyropoulos, N. V., \& Dalezios, N. R. (2017). Technological hazards. Environmental Hazards Methodologies for Risk Assessment and Management, 447.

Lough, J., Gupta, A. S., Power, S. B., Grose, M. R., McGree, S., McInnes, B. M., ... \& Wilson, L. (2015). Observed and projected changes in surface climate of tropical Pacific Islands. ofPaci c Island agriculture and forestry to climate change, 47.

Luetz, J.M. (2008). Planet prepare: Preparing coastal communities in Asia for future catastrophes, Asia Pacific Disaster Report. Bangkok, Thailand: World Vision International. Accessed 16 April 2016, https://luetz.com/docs/planet-prepare.pdf

Luetz, J.M. (2013). Climate migration: Preparedness informed policy opportunities identified during field research in Bolivia, Bangladesh and Maldives. Ph.D. dissertation, University of New South Wales. Retrieved May 31, 2016, from http://handle.unsw.edu.au/1959.4/52944

Luetz, J.M. (2017). Climate change and migration in the Maldives: Some lessons for policy makers. In W. Leal Filho (Ed.), Climate change adaptation in Pacific countries: Fostering resilience and improving the quality of life. Berlin, Germany: Springer.

Luetz J.M. (2018). Climate Change and Migration in Bangladesh: Empirically Derived Lessons and Opportunities for Policy Makers and Practitioners. In: Leal Filho W., Nalau J. (eds) Limits to Climate Change Adaptation. Climate Change Management. Springer, Cham.

Luetz J.M. \& Havea P.H. (2018). “We're not Refugees, We'll Stay Here Until We Die!”-Climate Change Adaptation and Migration Experiences Gathered from the Tulun and Nissan Atolls of Bougainville, Papua New Guinea. In: Leal Filho W. (eds) Climate Change Impacts and Adaptation Strategies for Coastal Communities. Climate Change Management. Springer, Cham. 
Nunn, P., Kumar, R. (2018) Understanding climate-human interactions in Small Island Developing States (SIDS): Implications for future livelihood sustainability. International Journal of Climate Change Strategies and Management, 10 (2), https://doi.org/10.1108/IJCCSM-012017-0012

Nurse, L.A., R.F. McLean, J. Agard, L.P. Briguglio, V. Duvat-Magnan, N. Pelesikoti, E. Tompkins, and Webb, A. (2014). Small islands. In: Climate Change 2014: Impacts, Adaptation, and Vulnerability. Part B: Regional Aspects. Contribution of Working Group II to the Fifth Assessment Report of the Intergovernmental Panel on Climate Change [Barros, V.R., C.B. Field, D.J. Dokken, M.D. Mastrandrea, K.J. Mach, T.E. Bilir, M. Chatterjee, K.L. Ebi, Y.O. Estrada, R.C. Genova, B. Girma, E.S. Kissel, A.N. Levy, S. MacCracken, P.R. Mastrandrea, and L.L. White (eds.)]. Cambridge University Press, Cambridge, United Kingdom and New York, NY, USA, pp. 1613-1654.

Ogo, T., Inomata, N., \& Yamamoto, Y. (1987). Plant species used in Papua New Guinea and Solomon Islands. Japanese journal of tropical agriculture 31(1), 16-27, Japan.

Ong, J. M., Jamero, M. L., Esteban, M., Honda, R., \& Onuki, M. (2016). Challenges in Build-BackBetter Housing Reconstruction Programs for Coastal Disaster Management: Case of Tacloban City, Philippines. Coastal Engineering Journal, 58(01), 1640010.

Ozturk, I., Al-Mulali, U., \& Saboori, B. (2016). Investigating the environmental Kuznets curve hypothesis: the role of tourism and ecological footprint. Environmental Science and Pollution Research, 23(2), 1916-1928.

McPherson, M., Counahan, M., \& Hall, J. L. (2015). Responding to Typhoon Haiyan in the Philippines. Western Pacific Surveillance and Response Journal, 6(Suppl 1), 1-4.

Mee, L. D., Dublin, H. T., \& Eberhard, A. A. (2008). Evaluating the Global Environment Facility: A goodwill gesture or a serious attempt to deliver global benefits? Global Environmental Change, 18(4), 800-810.

Monson, R., \& Foukona, J. D. (2014). 10 Climate-related displacement and options for resettlement in Solomon Islands. Land Solutions for Climate Displacement, 291.

Montz, B. E., Tobin, G. A., \& Hagelman III, R. R. (2017). Natural hazards: explanation and integration. Guilford Publications.

Nunn, P. D. (2013). The end of the Pacific? Effects of sea level rise on Pacific Island livelihoods. Singapore Journal of Tropical Geography, 34(2), 143-171.

Postance, B., Hillier, J., Dijkstra, T., \& Dixon, N. (2017). Extending natural hazard impacts: an assessment of landslide disruptions on a national road transportation network. Environmental Research Letters, 12(1), 014010.

Pradhan, B., \& Abdulwahid, W. M. (2017). Landslide Risk Assessment Using Multi-hazard Scenario Produced by Logistic Regression and LiDAR-Based DEM. In Laser Scanning Applications in Landslide Assessment (pp. 253-275). Springer International Publishing.

Ramos, G. E. (2013). 2. Combating climate change and biodiversity loss in a 'hot spot'mega-diversity country. Biodiversity and Climate Change: Linkages at International, National and Local Levels, 32 .

Robson, C. (2011). Real World Research: A Resource for Users of Social Research Methods in Applied Settings, (2nd Ed.). Sussex, A. John Wiley and Sons Ltd. 
Rosen, F., \& Olsson, P. (2013). Institutional entrepreneurs, global networks, and the emergence of international institutions for ecosystem-based management: the Coral Triangle Initiative. Marine Policy, 38, 195-204.

Salathé Jr, E. P., Hamlet, A. F., Mass, C. F., Lee, S. Y., Stumbaugh, M., \& Steed, R. (2014). Estimates of twenty-first-century flood risk in the Pacific Northwest based on regional climate model simulations. Journal of Hydrometeorology, 15(5), 1881-1899.

Taupo, T., \& Noy, I. (2017). At the very edge of a storm: The impact of a distant cyclone on Atoll Islands. Economics of Disasters and Climate Change, 1(2), 143-166.

Thomas, H., White, A., Whitford, L. \& Scrimgeour, R. (2017). Coral Reefs, Fisheries and Food Security- A case study Summary. European Commission, Brussels.

SIHE (2013). Solomon Islands Historical Encyclopaedia 1893-1978. Accessed, 1 Dec 2017, http://www.solomonencyclopaedia.net/biogs/E000336b.htm

Silverman, D. (2006). Interpreting qualitative data: Methods for analyzing talk, text and interaction. Sage, London.

Singhal, Y. K., Bhatnagar, R., Lal, B., \& Paliwal, B. (2016). Knowledge, attitudes, and practices of medical internship students regarding disaster preparedness at a tertiary-care hospital of Udaipur, Rajasthan, India. International Journal of Medical Science and Public Health, 5(8), 1613-1616.

Srinivasan, T. N., \& Rethinaraj, T. G. (2013). Fukushima and thereafter: Reassessment of risks of nuclear power. Energy Policy, 52, 726-736.

UNDP - United Nations Development Programme. (2007). Human development report 2007/2008. Fighting climate change: Human solidarity in a divided world. New York, USA: United Nations Development Programme. Retrieved April 16, 2016, from http://hdr.undp.org/sites/default/files/reports/268/hdr_20072008 en complete.pdf

UNHCR - United Nations High Commissioner for Refugees. (2009). Climate change and statelessness: An overview. Submitted by UNHCR, supported by the International Organization for Migration (IOM) and the Norwegian Refugee Council (NRC) to the 6th session of the Ad Hoc Working Group on Long-Term Cooperative Action (AWG-LCA 6) under UNFCCC, 1-12 June 2009, Bonn, Germany. Retrieved Dec 4, 2017, from http://www.unhcr.org/4a1e50082.html

Watson, S. J., Lucieer, V., Coffin, M. F., \& Whittaker, J. M. (2016). The Ontong Java Plateau uncovered: evidence for mass wasting on the flanks of Ontong Java and Nukumanu atolls. In Australian Earth Science Convention.

White, A. T., Aliño, P. M., Cros, A., Fatan, N. A., Green, A. L., Teoh, S. J., ... \& Venegas-Li, R. (2014). Marine protected areas in the Coral Triangle: progress, issues, and options. Coastal Management, 42(2), 87-106.

Wickham, F., Kinch, J., \& Lal, P. (2009). Institutional capacity within Melanesian countries to effectively respond to climate change impacts, with a focus on Vanuatu and the Solomon Islands. Secretariat of the Pacific Regional Environment Programme (SPREP).

Wise, R. M., Fazey, I., Smith, M. S., Park, S. E., Eakin, H. C., Van Garderen, E. A., \& Campbell, B. (2014). Reconceptualising adaptation to climate change as part of pathways of change and response. Global Environmental Change, 28, 325-336. 

Note. Honiara, Solomon Islands.

703

704 


\begin{tabular}{|c|c|c|}
\hline Challenge & Related literature & Possible solutions \\
\hline Sea level rise & $\begin{array}{l}\text { Albert, S., Leon, J. X., Grinham, A. R., Church, J. A., Gibbes, } \\
\text { B. R., \& Woodroffe, C. D. (2016). Interactions } \\
\text { between sea-level rise and wave exposure on reef } \\
\text { island dynamics in the Solomon } \\
\text { Islands. Environmental Research Letters, 11(5), } \\
\text { 054011. } \\
\text { Birk, T. (2012). Relocation of reef and atoll island } \\
\text { communities as an adaptation to climate change? } \\
\text { Learning from experience in Solomon } \\
\text { Islands. Climate Change and Human Mobility: } \\
\text { Global Challenges to the Social Sciences. } \\
\text { Cambridge University Press, Cambridge, 81-109. } \\
\\
\text { Luetz J.M. \& Havea P.H. (2018) "We're not Refugees, We'll } \\
\text { Stay Here Until We Die!"-Climate Change } \\
\text { Adaptation and Migration Experiences Gathered } \\
\text { from the Tulun and Nissan Atolls of Bougainville, } \\
\text { Papua New Guinea. In: Leal Filho W. (eds) Climate } \\
\text { Change Impacts and Adaptation Strategies for } \\
\text { Coastal Communities. Climate Change } \\
\text { Management. Springer, Cham. }\end{array}$ & $\begin{array}{l}\text { Migration / Relocation of } \\
\text { lower line communities to } \\
\text { higher lands, preferring } \\
\text { familiar and proximate } \\
\text { locations over unfamiliar } \\
\text { and non-proximate } \\
\text { destinations } \\
\text { Enhancing migration } \\
\text { through improving } \\
\text { adaptive capacity, } \\
\text { socioeconomic status, and } \\
\text { forward planning } \\
\text { Promoting education to } \\
\text { limit population growth, } \\
\text { while concurrently raising } \\
\text { in situ and ex situ adaptive } \\
\text { capacity }\end{array}$ \\
\hline Salt intrusion & $\begin{array}{l}\text { Birk, T., \& Rasmussen, K. (2014, February). Migration from } \\
\text { atolls as climate change adaptation: Current } \\
\text { practices, barriers and options in Solomon Islands. } \\
\text { In Natural Resources Forum (Vol. 38, No. 1, pp. 1- } \\
\text { 13). } \\
\text { McDonald, J. (2005). Provincial Strengthening and } \\
\text { Environmental Governance in the Solomon } \\
\text { Islands. Asia Pac. J. Envtl. L., 9, } 293 .\end{array}$ & $\begin{array}{l}\text { Introduction of salt } \\
\text { resistant crops } \\
\text { Relocating gardens to } \\
\text { higher ground }\end{array}$ \\
\hline Coastal erosion & $\begin{array}{l}\text { Albert, J. A., \& Schwarz, A. M. (2013). Mangrove } \\
\text { management in Solomon Islands: Case studies from } \\
\text { Malaita Province. CGIAR Research Program on } \\
\text { Aquatic Agricultural Systems. Penang, } \\
\text { Malaysia. Policy Brief: AAS-2013-14. } \\
\text { Gillie, R. D. (1992). Ranadi Beach Coastal Erosion Study: } \\
\text { Honiara, Guadalcanal, Solomon Islands. SOPAC. } \\
\text { Ministry of Environment, Climate Change, disaster } \\
\text { management and Meteorology (MECDM), 2016, } \\
\\
\text { http://www.mecdm.gov.sb/disasters/hazards/coastal- } \\
\text { erosion/13-disaster-management.html }\end{array}$ & $\begin{array}{l}\text { Targeted planting of } \\
\text { mangroves where possible } \\
\text { and proper planning of } \\
\text { coastline development } \\
\text { Moving to higher ground } \\
\text { where/when available } \\
\text { Disaster alerts and } \\
\text { corresponding risk } \\
\text { reduction activities }\end{array}$ \\
\hline Flash floods & $\begin{array}{l}\text { Keen, M., \& McNeil, A. (2016). After the Floods: Urban } \\
\text { Displacement, Lessons from Solomon } \\
\text { Islands. SSGM In Brief, } 13 . \\
\text { Reuben, R., \& Lowry, J. H. (2016). Effectiveness of } \\
\text { evacuation facilities in Honiara City, Solomon } \\
\text { Islands: a spatial perspective. Natural } \\
\text { Hazards, 82(1), 227-244. } \\
\text { Ministry of Environment, Climate Change, disaster } \\
\text { management and Meteorology (MECDM), } 2016 \\
\text { http://www.mecdm.gov.sb/disasters/hazards/coastal- } \\
\text { erosion/13-disaster-management.html }\end{array}$ & $\begin{array}{l}\text { Zoning and planning to } \\
\text { ensure communities are } \\
\text { well-prepared for } \\
\text { incidences of flooding } \\
\text { Where possible there } \\
\text { should be technology to } \\
\text { prevent or limit future } \\
\text { floods } \\
\text { Incorporating disaster risk } \\
\text { reduction into adaptation } \\
\text { planning }\end{array}$ \\
\hline Landslides & $\begin{array}{l}\text { Trustrum, N. A., Whitehouse, I. E., \& Blaschke, P. M. (1989). } \\
\text { Flood and landslide hazard, northern Guadalcanal, }\end{array}$ & $\begin{array}{l}\text { Ensuring that communities } \\
\text { are located away from } \\
\text { landslide prone areas }\end{array}$ \\
\hline
\end{tabular}




\begin{tabular}{|c|c|c|}
\hline & $\begin{array}{l}\text { Solomon Islands. DSIR Land and Soil Sciences } \\
\text { Contract Report, } 89(07) \text {. } \\
\text { McAdoo, B. G., Moore, A., \& Baumwoll, J. (2009). } \\
\text { Indigenous knowledge and the near field population } \\
\text { response during the } 2007 \text { Solomon Islands } \\
\text { tsunami. Natural Hazards, 48(1), 73-82. } \\
\text { Fritz, H. M., \& Kalligeris, N. (2008). Ancestral heritage saves } \\
\text { tribes during 1 April 2007 Solomon Islands } \\
\text { tsunami. Geophysical Research Letters, 35(1). }\end{array}$ & $\begin{array}{l}\text { Preserving important } \\
\text { historical knowledge to } \\
\text { guide communities in } \\
\text { identifying and } \\
\text { implementing appropriate } \\
\text { future development efforts }\end{array}$ \\
\hline $\begin{array}{l}\text { Cyclones and storm } \\
\text { surges }\end{array}$ & $\begin{array}{l}\text { Bayliss-Smith, T. P. (1988). The role of hurricanes in the } \\
\text { development of reef islands, Ontong Java Atoll, } \\
\text { Solomon Islands. Geographical Journal, 377-391. } \\
\text { Yates, L., \& Anderson-Berry, L. (2004). The Societal and } \\
\text { Environmental Impacts of Cyclone Zoe and the } \\
\text { Effectiveness of the Tropical Cyclone Warning } \\
\text { Systems in Tikopia and Anuta Solomon Islands: } \\
\text { December 26-29, 2002. Australian Journal of } \\
\text { Emergency Management, The, 19(1), 16. } \\
\text { Burslem, D. F. R. P., Whitmore, T. C., \& Brown, G. C. (2000). } \\
\text { Short - term effects of cyclone impact and long - } \\
\text { term recovery of tropical rain forest on } \\
\text { Kolombangara, Solomon Islands. Journal of } \\
\text { Ecology, 88(6), 1063-1078. }\end{array}$ & $\begin{array}{l}\text { Introducing community } \\
\text { level supported building } \\
\text { codes }\end{array}$ \\
\hline Food insecurity & $\begin{array}{l}\text { Rasmussen, K., May, W., Birk, T., Mataki, M., Mertz, O., \& } \\
\text { Yee, D. (2009). Climate change on three Polynesian } \\
\text { outliers in the Solomon Islands: impacts, } \\
\text { vulnerability and adaptation. Geografisk Tidsskrift- } \\
\text { Danish Journal of Geography, 109(1), 1-13. } \\
\text { Schwarz, A. M., Béné, C., Bennett, G., Boso, D., Hilly, Z., } \\
\text { Paul, C., ... \& Andrew, N. (2011). Vulnerability and } \\
\text { resilience of remote rural communities to shocks } \\
\text { and global changes: Empirical analysis from } \\
\text { Solomon Islands. Global Environmental } \\
\text { Change, 21(3), 1128-1140. } \\
\text { Cleasby, N., Schwarz, A. M., Phillips, M., Paul, C., Pant, J., } \\
\text { Oeta, J., .. \& Kori, M. (2014). The socio-economic } \\
\text { context for improving food security through land } \\
\text { based aquaculture in Solomon Islands: A peri-urban } \\
\text { case study. Marine Policy, 45, 89-97. } \\
\\
\text { Lacey, A. (2011). Shifting the gaze, shifting the agenda: } \\
\text { sustainable livelihoods in urban } \\
\text { Honiara. Development, 54(3), 368-375. }\end{array}$ & $\begin{array}{l}\text { Introduction of disaster } \\
\text { tolerant garden food, e.g., } \\
\text { giant swamp taro } \\
\text { Introduction of backyard } \\
\text { farming } \\
\text { Introduction of locally } \\
\text { managed protected areas } \\
\text { for communities to retain } \\
\text { safe access during and } \\
\text { after disaster events } \\
\text { Enhancing community } \\
\text { awareness on adaptation } \\
\text { strategies }\end{array}$ \\
\hline $\begin{array}{l}\text { Lower levels of salinity } \\
\text { result in coral bleaching }\end{array}$ & $\begin{array}{l}\text { Sulu, R., Cumming, R., Wantiez,L. N. T., Kumar, L., } \\
\text { Mulipola, A., Lober, M., ... \& Pakoa, K.. (2002). } \\
\text { Status of coral reefs in the southwest Pacific to } \\
\text { 2002: Fiji, Nauru, New Caledonia, Samoa, Solomon } \\
\text { Islands, Tuvalu and Vanuatu. Status of coral reefs of } \\
\text { the world, 181-201. }\end{array}$ & $\begin{array}{l}\text { Replanting of corals and } \\
\text { protection from over } \\
\text { harvesting }\end{array}$ \\
\hline
\end{tabular}


710 